\title{
Rendering the Arabic Contronym /Zann-a/ 'to surmise' into English in Four Qur'anic Translations
}

\author{
Manal Mohamed Abdel Nasser \\ Department of English, Faculty of Arts, Assiut University, Egypt \\ E-mail: manal.hashem@art.au.edu.eg
}

Received: Oct. 24, 2013 Accepted: Nov. 15, 2013 Published: December 8, 2013

doi:10.5296/ijl.v5i6.4451ＵRL: http://dx.doi.org/10.5296/ijl.v5i6.4451

\begin{abstract}
I?al-?aDdaad/ 'contronyms' represent a linguistic phenomenon that manifests the resourcefulness of the Arabic language. It means the encapsulation of two opposite meanings in one lexical item. It encourages and activates the role of context in decoding the intended meaning on the part of the speaker or the producer of the utterance. The present study explores the use of the lexical item /Zann-a/ 'to surmise' in the Glorious Qur'an. This item is an apparent example of contronyms because it simultaneously implies both doubt and certainty and it is only by the help of the context that its meaning is made clear. The study also examines the rendering of four Qur'anic Translations of this lexical item and how far these translations succeeded in presenting the exact meaning intended in the Qur'anic text. The study concludes that sense relations are very complicated and that every Qur'anic translation has its own touches in clarifying the various shadows of meaning encapsulated in the Qur'anic verses discussed.
\end{abstract}

Keywords: /?al-?aDdaad/ 'Contronyms', Inference, Oppositeness of meaning, Qur'anic translaton, /Zann-a/ 'to surmise' 


\section{Introduction}

The present study is a lexical semantic study interested in sense relations within a sentence and how these sense relations are explained in the light of the context or situation. It is worth mentioning that the direct meanings of the individual words in a particular utterance do not guarantee the understanding of the real message implied in this utterance. Hence the importance of context inference in reading what is hidden between the lines. Hudson (2000: 312) states that "linguistic form alone fails to explain all the meanings that we readily get from language." In other words, by the help of the context or the situation, one is able to infer some additional meanings which are absent in language forms.

Meaning is of uppermost importance to the translator. It enables him or her to choose the appropriate equivalent forms of the target language (TL) that best communicate the meaning of the original forms of the source language (SL). This is because "meaning is complicated, many-levelled, a 'network of relations' as devious as the channels of thought in the brain" (Newmark 1988: 51). This necessitates that the translator exerts a great effort to achieve his or her aim which is defined by Newmark (1988: 10) saying "there is wide but not universal agreement that the main aim of the translator is to produce as nearly as possible the same effect on his readers as was produced on the readers of the original." However, it is argued that there are no exact translations because human languages are not identical.

Hence the importance of the present paper in examining the following four Qur'anic Translations:

1- Ghâlî, Muhammad Mahmûd. (2008). Towards Understanding The Ever-Glorious Qur'ân.

2- Al-Hilâli \& Khân. (1417H). Translation of the Meanings of the Noble Qur'an In The English Language.

3- Ali, Abdullah Yusuf. (1938). The Holy Qur'an: Translation and Commentary.

4- Pickthall, Mohammed Marmaduke. (1930). The Meaning of the Glorious Koran.

The researcher is to focus on the rendering of the Arabic lexical item /Zann-a/ 'to surmise' into English in the four translations in order to decide on the appropriateness of these translations of the Qur'anic text (See the Appendix for the phonemic symbols used in the transcription of Arabic forms).

\section{Theoretical Framework}

\subsection{Oppositeness of Meaning in English}

It is claimed that every word in the language recalls its opposite in the minds of both the speaker and the hearer as soon as it is uttered. This, of course, implies that "every word in the vocabulary has an opposite, and only one opposite" (Lyons 1977: 1/270). The same idea is echoed by Radford, Atkinson, Britain, Clahsen, \& Spencer (1999:199) stating that "oppositeness of meaning is a pervasive semantic relation in the lexicons of human languages and it comes in several varieties." The linguistic term assigned by Lyons (1977: 1/271) for oppositeness of meaning between lexical items is antonymy and pairs of lexical items which 
are related by this sense relation are called antonyms. There are many examples of antonyms in English such as 'man': 'woman', 'admit': 'deny', 'black': 'white', and 'quickly': 'slowly'.

Interestingly, all antonyms are not of the same kind. They are divided, in terms of gradability, into gradable (e.g. 'big': 'mall') and ungradable (e.g.'alive': 'dead') antonyms. Ungradable opposites are also called absolute opposites and they draw a sharp line between two properties. In this sense, what is not $\mathrm{X}$ is necessarily $\mathrm{Y}$. Thus they "divide the universe-of-discourse . . . into two complementary subsets" (Ibid). Gradable opposites, however, permit the presence of a common space in between the two ends which is graded in the two opposing directions. This allows the use of 'more' or 'less' with gradable adjectives in comparison. Palmer (1981: 95) also adds that "since antonyms are gradable, there are often intermediate terms. Thus we have not just hot/cold, but hot/warm/cool/cold, with the intermediate warm and cool forming a pair of antonyms themselves." It is worth mentioning that gradable and ungradable opposites are also called contraries and contradictories, respectively (Lyons 1977:1/272).

In terms of the form, lexical opposites are divided into morphologically related opposites (e.g. 'married': 'unmarried') and morphologically unrelated opposites (e.g. 'easy': 'difficult'). Furthermore, another fine distinction is made between a privative opposition and an equipollent opposition. The former is said to be "a contrastive relation between two lexemes, one of which denotes some positive property and the other of which denotes the absence of that property: e.g., 'animate': 'inanimate'." The latter, on the other hand, is "a relation in which each of the contrasting lexemes denotes a positive property: e.g., 'male': 'female'." (Ibid: 279).

A third type of sense relations of oppositeness of meaning is the class of converses. Lyons (1977: 1/280) cites:

Converse relations ... are especially common in areas of the vocabulary having to do with reciprocal social roles ('doctor': 'patient', 'master'/'mistress': 'servant', etc.) and kinship relations ('father'/ 'mother': 'son'/'daughter', etc.), on the one hand, and temporal and spatial relations ('above': 'below', 'in front of' : 'behind', 'before': 'after', etc.), on the other.

The fourth type of binary opposites introduced by Lyons (1977: 1/281) is the directional opposites such as 'east': 'west'. The fifth type of sense relations is the non-binary contrast which "holds between lexemes in many-member sets" such as the days of the week and the months of the year. This sense relation is "described as incompatibility" (Ibid: 288).

\subsection{Oppositeness of Meaning in Arabic}

Oppositeness of meaning is not the monopoly of one language. It is a common trait of all human languages. In Arabic, among the promoting causes of the oppositeness of meaning are Itadaa9i l-ma9aani l-mutaDaaddah/ 'the association of opposite senses' and /?at-taSaahub-u ð-ðihniil 'the mental company' (Haidar 2005: 154). Arabic is rich in examples of antonyms such as /rajul/ 'man': /?imra?ah/ 'woman', /yudaafi9/ 'to defend': /yuhaajim/ 'to attack', /Sawaab/ 'right': /xaTa?/ 'wrong', and /bi-sur9ah/ 'quickly': /bi-buT?/'slowly'. 
Again, in Arabic, we can find gradable antonyms (e.g. /kabiir/ 'big': /Sagiir/ 'small') and ungradable antonyms (e.g. / $\hbar a y y /$ 'alive': /mayyit/ 'dead'). We can also find morphologically related and unrelated opposites represented in the pairs /sa9iid/ 'happy': /gair sa9iid/ 'unhappy' and /sa9iid/ 'happy': /šaqiyy/ 'sad', respectively. It is worth mentioning that these two types of morphologically related and unrelated opposites are known, in Arabic, as /?aT-Tibaaq ?as-salbii/ 'negative antonymy' and /?aT-Tibaaq ?al-?iijaabii/ 'positive antonymy', respectively. Moreover, converses are evident in Arabic in reciprocal social roles (e.g. /yaštarii/ 'to buy': /yabiig/ 'to sell'), kinship relations (e.g. /?al-?ab/ 'father': /?al-?ibn/ 'son') and temporal and spatial relations such as /qabl/ 'before': /ba9d/ 'after' and /?a9laal 'above': /?asfal/ 'below', respectively. Directional opposites as well as non-binary contrast are

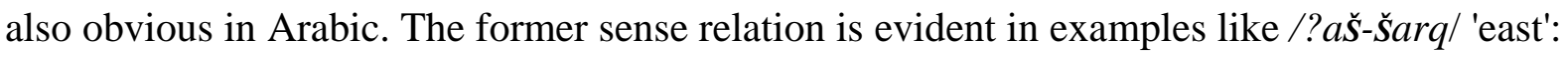
/?al-garb/ 'west' and /?aš-šamaal/ 'north': /?al-januub/ 'south'. The latter is manifested in the many-member set of colour words in which /?abyaD/ 'white', for example, stands in contrast with /? aswad/ 'black' or with /? aћmr/ 'red' or with a third colour whatsoever. That is they are linked with the relationship of incompatibility holding between the different members of the colour set. In sum, the same sense relations discussed in English are also found in Arabic even if they have not got the same technical terms.

\subsection{Contronyms in English}

Contronyms are evident in English. Lederer (1979: 167) defines them as "single words for which two contradictory meanings survive." The term contronym is also spelt contranym which is defined as "a word that can mean the opposite of itself, as, for example, clip (to attach or to cut off)" (Hendrickson 2008: 202). Moreover, it is also referred to as autantonym which stands for "a word that has come to mean its opposite. An example is the word fast, which in the case of a fast runner means a runner who runs rapidly, but in the case of a fast color means a color that doesn't run at all" (Ibid: 45-46). In this way, this term resembles the double-faced coin, with each face carrying the opposite meaning of the other one, and accordingly, this type of words is sometimes called the Janus words after the double-faced Janus, the Roman god of gates (Ibid: 453). Below is a list of some English contronyms supported by examples:

2.3.1 Dust: to remove dust from something vs to sprinkle something with powder:

a- I dusted my seat.

b- I dusted the pie with sugar.

2.3.2 Left: remaining vs departed

a- What is left will be put into use next time.

b- He has just left.

\subsubsection{Let: allow vs prevent}

a- Please, let me go.

b- Let ball (a tennis ball that is prevented from its natural course by the net.) 


\section{Macrothink}

\subsubsection{Put out: produce vs extinguish}

a- The lamp puts out enough light for me to read.

b- The fireman puts the fire out.

\subsubsection{Root: establish vs exterminate}

a- His faith is deeply rooted.

b- I wish I could root out evil from the whole world.

\subsection{Contronyms in Arabic}

The Arabic language is rich in /?al-?aDdaad/ 'contronyms' which refer to the phenomenon of a single word that has two opposite meanings such as /?al-baSiir/ 'sighted' which refers to both the sighted and the unsighted or the blind. And the understanding of the intended meaning is, of course, context-dependent. However, this phenomenon of /?al-?aDdaad/ 'contronyms' is not to be confused with either /?al-muštarak ?al-lafZii/ 'homonymy' or /ta9adud ?al-ma9aanii/ 'polysemy' represented by the lexemes /saaq/ 'leg' and /rabii9/ 'spring', respectively. /saaq/ 'leg' stands for a part of the human body and a part of the plant structure. /rabii9/ 'spring' stands for three meanings: a name of a person, a name of two Hijri months (Rabii9 I, the third Hijri month and Rabii9 II, the fourth Hijri month) and a name of one of the four seasons of the year. All these sense relations are problematic and are only made clear by the use of context-clues. What is unique about/?al-?aDdaad/ 'contronyms' is the relation of oppositeness of meaning evident in one single item. While in the case of /?al-muštarak ?al-lafZii/ 'homonymy' and /ta9adud ?al-ma9aanii/ 'polysemy', the meanings denoted are different but not contradictory.

Many Arab linguists try to explain the phenomenon of /?al-?aDdaad/ 'contronyms'. Al-samara?i (1997: 98) believes that this phenomenon results from linguistic evolution and semantic change. To prove this idea, NaSSar (2003: 20) cites the example of the verb /yubaadil/ 'to exchange' which meant both /yaštarii/ 'to buy' and /yabii9/ 'to sell'. The reason he cites this example is that buying and selling depended, in the past, on exchanging goods before the introduction of money. Moreover, the widening of lexical meaning and the many dialects of the Arabic language are also mentioned in the justification of the phenomenon in question. The former case is made clear by any lexeme which gets a new meaning by the passage of time while it keeps the old one (NaSSar 2003: 22; Al-Anbari 1987: 8). The latter is explained in the light of the different meanings assigned to the same lexeme by the various diatects of the Arabic language (NaSSar 2003: 21; Al-Anabari 1987: 11). One of these lexemes, for example, is /?al-qur?/ 'menstruation' which stands for /?aT-Tuhr/ 'to perform an ablution' in Hejaz and for /?al-haiD/ 'menses' in Iraq (NaSSar 2003: 40-41). Another example is /sudfa/ 'darkness' which means /Zulmah/ 'dusk' in the dialect of Tameem and /Daw?/ 'light' in the dialect of Qais (Ibid: 41).

Arab linguists put some conditions for a lexeme to be sorted among /?al-?aDdaad/ 'contronyms' (NaSSar 2003: 26-31). Firstly, the morphological form of the lexical item that has two opposite meanings should be the same in the two cases. An example is the lexical 


\section{Macrothink}

International Journal of Linguistics ISSN 1948-5425 2013, Vol. 5, No. 6

item /ma?tam/ 'obsequies' which refers to a group of women gathering either in a happy occasion or in a funeral ceremony and in the two cases it has the same form [maf9al]. Secondly, the two opposite meanings should be in Standard Arabic. Thirdly, they should also be common among Arabs and not obsolete. Fourthly, the two meanings of the same lexical item should be genuine. That is none of them should be figurative like the case of $/ \mathrm{ka}$ ? s/ 'cup' which is used to denote both the container (genuine meaning) and the contained (figurative meaning) (Ibid: 55). In fact, there have been many disputes among Arab linguists about this fourth condition. Some adopted it while others rejected it.

\subsection{Contronyms in the Glorious Qur'an}

This phenomenon is evident in the Glorious Qur'an. The contronym that occurs with high frequency is the Arabic verb /Zann-a/ 'to surmise' which is of interest to the present study. It has the frequency of sixty-nine occurrences. However, other examples of /?al-?aDdaad/ 'contronyms' are also evident in the Glorious Qur'an as follows:

\subsection{1/?asarr-a/}

This item stands, in Arabic, for both 'conceal' and 'declare' alike (Al-Anbari 1987: 45):

a) The meaning of 'conceal':

/wa ?asarru n-najwa llaðiina Zalamuu/ (Qur'an 21:3)

The wrong-doers conceal their private counsels. (Ali 1938: 822)

b) The meaning of 'declare':

/wa ?asarru n-nadaamata lammaa ra?awu 1-9aðaab/ (Qur'an 10: 54)

They would declare (their) repentance when they see the penalty. (Ali 1938: 499)

\subsection{2 /bayn/}

Again, this lexical item is an example of /?al-?aDdaad/ 'contronyms' which is well known for the meaning of 'separation'. However, it appears in the Glorious Qur'an with the meaning of connection and relation (Al-Anbari 1987: 75-76) as follows:

/laqad ttaqaTTa9a baynakum/ (Qur'an 6: 94)

So now all relations between you have been cut off (Ali 1938: 315)

\subsection{3 /rajaa/}

Al-Saleh (2010: 177) states that /?ar-rajaa?/ 'hope' stands for both 'hope' and 'fear' as follows:

a) The meaning of 'hope':

/wa yarjuuna raћmatahuu wa yaxaafuuna 9aðaabah/ (Qur'an 17: 57)

They hope for His mercy and fear His wrath. (Ali 1938: 710) 
b) The meaning of 'fear':

/maa lakum laa tarjuuna lillaahi waqaara/

(Qur'an 71: 13)

What is the matter with you, that [you fear not Allâh (His punishment), and ] you hope not for reward ... (Al-Hilâlî \& Khân 1417H: 788)

\subsection{4 /qasaTa/}

This item stands for doing justice and injustice alike (Al-Anbari 1987: 58). Representative examples from the Glorious Qur'an are the following:

a) The meaning of 'doing justice':

/?inna llaaha yuhibb-u l-muqsiTiin/ (Qur'an 5: 42)

God loveth those who judge in equity (Ali 1938: 255)

b) The meaning of 'doing injustice':

/wa ?amma l-qaasituuna fakaanuu lijahannama hataba/ (Qur'an 72: 15)

\subsection{5 /waraa?/}

Al-Anbari (1987: 68) states that the contronym /waraa?/ occurs with the meanings of 'behind' and 'in front of':

a) The meaning of 'befind':

/laa yuqaatiluunakum jamii9an ?illaa fii quram muhaSSanatin ?aw miw waraa?i judur/ (Qur'an 59: 14)

They will not fight you (even) together, except in fortified townships, or from behind walls. (Ali 1938: 1525)

b) The meaning of 'in front of':

/miw waraa?ihim jahannam/ (Qur'an 45: 10)

In front of them is Hell. (Ali 1938: 1356)

\section{Discussions and Results}

The word /?al-?aDdaad/ 'contronyms' is the plural of /Didd/ 'opposite'. It is a semantic phenomenon which stands for the most problematic sense relation of lexical items in Arabic. This phenomenon is a main source of ambiguity. It presents a serious difficulty in decoding the meaning in general and in translating it in particular. The main objective in this stage is to determine which translation of the four Qur'anic translations mentioned above is the most appropriate in conveying the meaning of the verb /Zann-a/ 'to surmise' as it is presented in the Glorious Qur'an. Decision is reached after consulting an authority in Qur'anic interpretation. Ibn ManZur (1981: 4/2762) states that /?aZ-Zann-u/ 'surmising' indicates "both certainty and doubt. Yet, certainty, here, is not the type that is reached by eye witnessing but rather by means of thinking and contemplation. However, certainty that is reached by eye witnessing 
is known as knowledge." (translation mine). Moreover, Al-9askari (1997: 98-99) explains the fine distinction between /?aZ-Zann-u/ 'surmise' and /?aš-šakk-u/ 'doubt'. He cites that /?aš-šakk-u/ 'doubt' is the evenness of the two contradictory extremes, while /?aZ-Zannu/ 'surmise' is the predominance of one extreme over the other. On the contrary, /?al-9ilm/ 'knowledge' is reached by eye witnessing.

The lexical item /Zann-a/ 'to surmise' is mentioned in the Glorious Qur'an, sixty-nine times in twenty-two different forms as presented in Table 1:

Table 1. Forms of the Contronym /Zann-a/ 'to surmise' in the Glorious Qur'an

\begin{tabular}{|c|c|c|c|}
\hline No & Form & Meaning & Occurrences \\
\hline 1 & /Zann-a/ & he surmised & 7 \\
\hline 2 & /Zann-aal & they two surmised & 1 \\
\hline 3 & /Zanan-tu/ & I surmised & 1 \\
\hline 4 & /Zanan-tum/ & you (all) surmised & 6 \\
\hline 5 & /Zanan-naa/ & we surmised & 2 \\
\hline 6 & /Zann-uu/ & they surmised & 9 \\
\hline 7 & /?aZunn-u/ & I surmise & 3 \\
\hline 8 & /la-?aZunn-u-kal & I do surmise that you & 2 \\
\hline 9 & /la-?aZunn-u-hu/ & I do surmise that he & 2 \\
\hline 10 & /ta-Zunn-u/ & surmising & 1 \\
\hline 11 & /ta-Zunn-uuna/ & you all surmise & 2 \\
\hline 12 & /na-Zunn-u/ & we surmise & 1 \\
\hline 13 & Ina-Zunn-u-kal & we surmise that you & 2 \\
\hline 14 & /na-Zunn-u-kum/ & we surmise that you all & 1 \\
\hline 15 & /ya-Zunn-u/ & he surmises & 2 \\
\hline 16 & /ya-Zunn-uunal & they surmise & 5 \\
\hline 17 & /?aZ-Zann-u/ & surmise (noun) & 15 \\
\hline 18 & /Zann-aal & surmise (noun) & 2 \\
\hline 19 & /Zann-u-kum/ & your surmise & 2 \\
\hline 20 & /Zann-a-hu/ & his surmise & 1 \\
\hline 21 & /?aZ-Zunuunaal & surmises & 1 \\
\hline 22 & /?aZ-Zaanniina/ & they who surmise & 1 \\
\hline Total & & & 69 \\
\hline
\end{tabular}

In the rest of this section, the researcher is going to discuss each form with a representative example.

\section{1 /Zann-a/ 'he surmised'}

This form has been stated seven times in the Glorious Qur'an. The following verse is a representative example:

Iwa qaala lillaði Zann-a ?annahuu naajim minhuma ðkurni 9inda rabbik/(Qur'an 12: 42).

I. And he said to the one of the two (that) he expected would be delivered, "Mention me in the presence of your lord" (Ghâlî 2008: 240).

II. And of the two, to that one whom he considered about to be saved, he said: "Mention me 
to thy lord" (Ali 1938: 565).

III. And he said to the one whom he knew to be saved: "Mention me to your Lord" (Al-Hilâlî \& Khân 1417H: 309).

IV. And he said unto him of the twain who he knew would be released: Mention me in the presence of thy Lord (Pickthall 1930: 177)

The Qur'anic context, here, is 'Joseph's story'. Joseph interpreted the dream of the cup-bearer, who was in Joseph's company in prison, and was certain that he would be saved. This piece of information acts as the contextual clue that leads one to believe that /Zann-a/ 'he surmised' in this verse indicates certainty. In Funk \& Wagnalls (1967), 'to expect' means "to look forward to as certain" (1/446), and 'to consider' means "to think about or . . . examine mentally" (1/278), while 'to know' means "to perceive or understand clearly or with certainty" (1/706). Obviously, the verbs 'expected' and 'knew' succeed in conveying the exact meaning of certainty intended in the above verse. However, the verb 'considered' in Ali (1938: 565) lacks the sense of certainty, based on evidence, understood in this Qur'anic verse. It is worth mentioning that 'expected' is distinguished by the sense of expectancy that strengthens the meaning of certainty. Table 2 shows the various English translations of this form and their frequencies in the four Qur'anic translations.

Table 2. English Translations of the form /Zann-a/ 'he surmised'

\begin{tabular}{|c|c|c|c|c|}
\hline \multirow{2}{*}{ Translation } & \multicolumn{5}{|c|}{ Number of Occurrences } \\
\cline { 2 - 5 } & Ghâlî̀ & Ali & Al-Hilâlî \& Khân & Pickthall \\
\hline Surmise & 4 & - & - & - \\
\hline Think & 1 & 2 & 3 & 3 \\
\hline Deem & - & - & - & - \\
\hline Expect & 2 & - & - & - \\
\hline Consider & - & 1 & - & - \\
\hline Know & - & - & - & - \\
\hline put in mind & - & 1 & 1 & - \\
\hline Imagine & - & 1 & - & 1 \\
\hline Gather & - & 1 & 1 & - \\
\hline Guess & - & - & 1 & 7 \\
\hline Conclude & - & 1 & 7 & \\
\hline Total & 7 & 7 & & \\
\hline
\end{tabular}

\section{2 /Zann-aa/ 'they two surmised'}

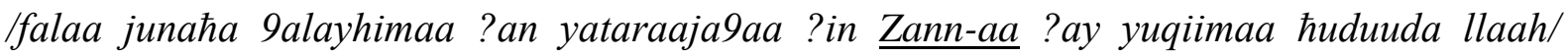
(Qur'an 2: 230)

I. . . then there is no fault in them (both) to return to each other, in case they expect that they will keep within the bounds of Allâh (Ghâlî 2008: 36).

II. In that case there is no blame on either of them if they re-unite, provided they feel that they can keep the limits ordained by God (Ali 1938: 91).

III. Then . . . it is no sin on both of them that they reunite, provided they feel that they can keep the limits ordained by Allâh （Al-Hilâlî \& Khân 1417H: 50). 
IV. Then . . . it is no sin for both of them that they come together again if they consider that they are able to observe the limits of Allah (Pickthall 1930: 54)

The Qur'anic context, this time, concerns the case of the third divorce which is irrevocable unless the woman marries another husband and he divorces her. After that the couple re-union is possible only if the husband and wife are certain that they can keep the limits set by Allah. Again, the verb /Zann-aa/ 'they two surmised' indicates certainty which is a must now because there is no room for any wrong or rush decisions. 'Expect' in the first translation accurately conveys the intended meaning. The verb 'feel', which means "to be convinced of intellectually; believe in . . . " (Funk \& Wagnalls 1967: 1/464), and the verb 'consider' also succeed in conveying the intended meaning on the ground that certainty in this case is a decision which is reached after much thinking. That is there is no clear evidence in this case, that is why 'feel' and 'consider' work well this time. In other words, one is inclined to classify certainty into certainty based on evidence that is evident in 3.1 and the evidence is the interpretation of the dream of the cup-bearer, and certainty based on careful thinking and contemplation that is evident in 3.2. It is worth mentioning that 'expect' is privileged over the other three translations by the fact that it implies an anticipation of a future reaction as a result of deep thinking. Table 3 shows the various English translations of this form and their frequencies in the four Qur'anic translations.

Table 3. English Translations of the form /Zann-aa/ 'they two surmised'

\begin{tabular}{|c|c|c|c|c|}
\hline \multirow{2}{*}{ Translation } & \multicolumn{4}{|c|}{ Number of Occurrences } \\
\cline { 2 - 5 } & Ghâlî & Ali & Al-Hilâlî \& Khân & Pickthall \\
\hline Expect & 1 & - & - & - \\
\hline Feel & - & 1 & 1 & 1 \\
\hline Consider & - & - & - & 1 \\
\hline Total & 1 & 1 & 1 & - \\
\hline
\end{tabular}

\section{3 /Zanan-tu/'I surmised'}

\section{I?inni Zanantu ?anni mulaaqin hisaabiyah/ (Qur'an 69: 20)}

I. Surely I expected that I should meet my reckoning (Ghâli 2008: 567).

II. "I did really understand that my Account would (One Day) reach me!" (Ali 1938: 1599)

III."Surely, I did believe that I shall meet my Account!" (Al-Hilâlî \& Khân 1417H: 781)

IV. Surely I knew that I should have to meet my reckoning (Pickthall 1930: 412).

Again, /Zanan-tu/ 'I surmised' in this Qur'anic context is another instance of certainty because the speaker in this verse is one of the believers. In fact, it is frankly stated in the Qur'anic interpretations that /?aZ-Zann-u/ 'surmise' on the part of a believer is certainty and on the part of a disbeliever is doubt (Al-Shawkani 1983: 5/284). Obviously, 'expected' and 'knew' could convey the meaning of certainty implied in the above verse. Certainty, this time, is based on evidence which is faith in Allah. As for the other two translations, 'understand' means "believe" (Funk \& Wagnalls 1967: 2/1368), and 'believe' means "have confidence" (Ibid: 1/128). Accordingly, these two translations are also adequate for conveying the intended meaning. However, 'expected' is favoured with the senses of anticipation and alertness which 
force the believer to keep an eye on his words and actions lest he/she should be reckoned guilty. Table 4 shows the various English translations of this form and their frequencies in the four Qur'anic translations.

Table 4. English Translations of the form /Zanan-tu/ 'I surmised'

\begin{tabular}{|c|c|c|c|c|}
\hline \multirow{2}{*}{ Translation } & \multicolumn{4}{|c|}{ Number of Occurrences } \\
\cline { 2 - 5 } & Ghâlî & Ali & Al-Hilâlî \& Khân & Pickthall \\
\hline expect & 1 & - & - & - \\
\hline understand & - & 1 & - & - \\
\hline believe & - & - & 1 & - \\
\hline know & - & - & - & 1 \\
\hline Total & 1 & 1 & 1 & 1 \\
\hline
\end{tabular}

\section{4 /Zanan-tum/'you all surmised'}

/bal Zanantum ?al lan yanqaliba rrasuulu wa-lmu?minuuna ?ilaa ?ahliihim ?abadaal (Qur'an 48:12)

1- No indeed, (but) you surmised that the Messenger and the believers would never come over to their own families at all, ... (Ghâlî 2008: 512).

II- "Nay, ye thought that the Apostle and the Believers would never return to their families; ... (Ali: 1394).

III-"Nay, but you thought that the Messenger and the believers would never return to their families, ... (Al-Hilâlî \& Khân 1417H: 694).

IV- Nay, but ye deemed that the messenger and the believers would never return to their own folk, ... (Pickthall 1930: 366).

The speech, this time, is addressed to the hypocrites whose faith was unstable that they did not join the Prophet and the believers at Hudaibiya. /Zanan-tum/ 'you all surmised' in this Qur'anic context indicates doubt, especially when /?aZ-Zann-u/ 'surmise' comes from those hypocrites of unstable faith. The verb 'surmised' in the first translation means to "infer (something) from incomplete or uncertain evidence" (Hanks 1986: 1533), and to "infer doubtfully" (Hawkins \& Allen 1991: 1456). In this way, the first translation directly conveys the sense of doubt and uncertainty. The other two verbs 'thought' and 'deemed' convey the same meaning but indirectly. This is because 'to think' means "to examine in the mind; meditate upon" (Funk \& Wagnalls 1967: 2/1305); and 'to deem' means "to judge; think" (Ibid: 1/334). So they are approximately the same. And since those people are not good, what goes on inside their minds results in misjudgments and doubts. In this way, both 'thought' and 'deemed' indirectly indicate doubt as the mental processes of thinking and meditating are processed in confused minds. Thus, the first translation is distinguished from the others by using the most accurate equivalent. Table 5 shows the various English translations of this form and their frequencies in the four Qur'anic translations. 
Table 5. English Translations of the form /Zanan-tum/ 'you (all) surmised'

\begin{tabular}{|c|c|c|c|c|}
\hline \multirow{2}{*}{ Translation } & \multicolumn{4}{|c|}{ Number of Occurrences } \\
\cline { 2 - 5 } & Ghâlî & Ali & Al-Hilâlı̂ \& Khân & Pickthall \\
\hline surmise & 6 & - & - & - \\
\hline think & - & 4 & 6 & 2 \\
\hline deem & - & - & - & 3 \\
\hline entertain & - & 1 & - & - \\
\hline conceive & - & 1 & - & - \\
\hline suppose & - & - & - & 6 \\
\hline Total & 6 & 6 & 6 & 1 \\
\hline
\end{tabular}

\section{5 /Zanan-naal 'we surmised'}

Iwa ?annaa Zanannaa ?al lan taquul-a l?insu wa-ljinnu 9ala llaahi kaðibaal (Qur'an 72:5)

I- And that we surmised that humankind and the jinn would never speak against Allâh a lie (Ghâlî 2008: 572).

II- 'But we do think that no man or spirit should say aught that is untrue against God (Ali 1938: 1625-1626).

III- 'And verily, we thought that men and jinn would not utter a lie against Allâh (Al-Hilâlî \& Khân 1417H: 790).

IV- And lo! we had supposed that humankind and Jinn would not speak a lie concerning Allah (Pickthall 1930: 417).

The speakers, in this verse, are the jinns. They describe a past condition before listening to the recital of the Glorious Qur'an for the first time. Actually, listening to the Glorious Qur'an is the turning point that made them believe that their supposition was false and had no foundation. The present situation implies no room for consideration and making inferences. It seems it came to them spontaneously that nobody, human being/jinn, dares to tell lies about Allah. Accordingly, the fourth translation is the most accurate. It simply describes the situation as it is. The item 'suppose' means "assume, esp. in default of knowledge" (Hawkins \& Allen 1991: 1454). That is the jinns said so as a possibility or as a hypothesis but without having certain knowledge. As for the verbs 'surmised' and 'do think'/ 'thought', they transfer the idea of the lack of knowledge but again they imply inference and mental examination which are too complicated for the present situation which seems natural and unplanned. To sum up, the item /Zanan-naa/ 'we surmised' represents another case of doubt and uncertainty. Table 6 shows the various English translations of this form and their frequencies in the four Qur'anic translations.

Table 6. English Translations of the form /Zanan-naa/ 'we surmised'

\begin{tabular}{|c|c|c|c|c|}
\hline \multirow{2}{*}{ Translation } & \multicolumn{4}{|c|}{ Number of Occurrences } \\
\cline { 2 - 5 } & Ghâlî & Ali & Al-Hilâlî \& Khân & Pickthall \\
\hline surmise & 2 & - & - & - \\
\hline think & - & 2 & 2 & 1 \\
\hline suppose & - & - & - & 1 \\
\hline know & - & - & - & 2 \\
\hline Total & 2 & 2 & 2 & - \\
\hline
\end{tabular}




\section{6 /Zann-uu/ 'they surmised'}

/wa ra?a lmujrimuиna n-naara fa-Zannuи ?anna-hum muwaaqi9uu-haa/(Qur'an 18: 53)

I- And the criminals will see the Fire; so they expect that they are falling into it . . (Ghâlî 2008: 299).

II- . . . and the sinful shall see the Fire and apprehend that they have to fall therein (Ali 1938: $745)$.

III- And the Mujrimûn (criminals, polytheists, sinners) shall see the fire and apprehend that they have to fall therein (Al-Hilâlî \& khân 1417H: 393).

IV- And the guilty behold the Fire and know that they are about to fall therein (Pickthall 1930: 216).

The context of situation, here, is the Day of Judgment. On that day, the criminals will see the Fire of Hell surrounding them from all sides to the extent that they will be certain that there is no escape from it and that they are, for sure, falling into it. So, /Zann-uu/ 'they surmised', in this context, indicates certainty. Both the verbs 'expect' and 'know', in the first and the fourth translations, respectively, adequately convey this meaning of looking for something with confidence and certainty. As for the verb 'apprehend', it means "to lay hold of or grasp mentally; grasp a truth" (Funk \& Wagnalls 1967: 1/72). Again, it conveys the meaning of certainty based on evidence which is the scene of the Fire. Moreover, the first translation of /Zann-uu/ 'they surmised' is distinguished by the sense of expectancy and being on the verge of falling into the Fire. Table 7 shows the various English translations of this form and their frequencies in the four Qur'anic translations.

Table 7. English Translations of the form /Zann-uu/ 'they surmised'

\begin{tabular}{|c|c|c|c|c|}
\hline \multirow{2}{*}{ Translation } & \multicolumn{4}{|c|}{ Number of Occurrences } \\
\cline { 2 - 5 } & Ghâlî & Ali & Al-Hilâlî \& Khân & Pickthall \\
\hline expect & 5 & - & - & - \\
\hline think & - & 6 & 6 & 1 \\
\hline suppose & - & - & - & 2 \\
\hline perceive & - & 2 & 2 & 1 \\
\hline bethink & - & - & - & 3 \\
\hline deem & - & - & - & - \\
\hline apprehend & - & 1 & 1 & 1 \\
\hline know & - & - & - & - \\
\hline surmise & 4 & - & - & 9 \\
\hline Total & 9 & 9 & 9 & \\
\hline
\end{tabular}

\section{7 /?aZunn-u/'I surmise'}

Iwa maa ?aZunnu ssaa9ata qaa?imatan wa- la?ir rudidttu ?ilaa rabbii la?ajidanna xayram minhaa munqalabaa/ (Qur'an 18: 36)

I- And in no way do I expect that the Hour is coming up; and indeed in case I am turned back to my Lord, indeed I will definitely find a more charitable recourse than (this) (Ghâlî 2008: 298). 
II- "Nor do I deem that the Hour (of Judgment) will (ever) come: even if I am brought back to my Lord, I shall surely find (there) something better in exchange" (Ali 1938: 740)

III- 'And I think not the Hour will ever come, and if indeed I am brought back to my Lord, (on the Day of Resurrection), I surely shall find better than this when I return to Him" (Al-Hilâlî \& Khân 1417H: 390).

IV-I think not that the Hour will ever come, and if indeed I am brought back unto my Lord I surely shall find better than this as a resort (Pickthall 1930: 215).

The speaker in this Qur'anic verse is a disbeliever who denies the Day of Judgment. As it is mentioned above in example 3.3, /?aZ-Zann-u/ 'surmise' on the part of a disbeliever is always doubt and has no solid foundations. Also, the verbs 'expect', 'deem' and 'think', which are used in the four translations of the verse in question, are said, in the above examples, to indicate certainty. However, they are used, this time, to indicate the opposite sense. In order to cope with the meaning of doubt and the use of the negative particle /maa/ 'not' which precedes the verb /?aZunn-u/ 'I surmise' in the Arabic version of the Qur'anic verse, the verbs in the four English translations are negated. This is how the meanings of doubt, uncertainty and denial are communicated in the four translations. Table 8 shows the various English translations of this form and their frequencies in the four Qur'anic translations.

Table 8. English Translations of the form /?aZunn-u/ 'I surmise'

\begin{tabular}{|c|c|c|c|c|}
\hline \multirow{2}{*}{ Translation } & \multicolumn{4}{|c|}{ Number of Occurrences } \\
\cline { 2 - 5 } & Ghâlî & Ali & Al-Hilâlî \& Khân & Pickthall \\
\hline expect & 3 & - & - & - \\
\hline deem & - & 2 & - & 1 \\
\hline think & - & 1 & 3 & 2 \\
\hline Total & 3 & 3 & 3 & 3 \\
\hline
\end{tabular}

\section{8 /la-?aZunn-u-ka/ 'I do surmise that you'}

/wa ?inni la-?aZunn-u-ka yaa fir9awnu maөbuuraal (Qur'an 17: 102)

I- And surely I indeed surmise, O Firc ${ }^{c}$ awn, you are detrimented (Ghâlî 2008: 292).

II- . . . and I consider thee indeed, O Pharaoh, to be one doomed to destruction! (Ali 1938: 724).

III- And I think you are, indeed, O Fir'aun (Pharaoh) doomed to destruction (away from all good)! (Al Hilâlî \& Khân 1417H: 388).

IV- . . , and lo! (for my part) I deem thee lost, O Pharaoh

(Pickthall 1930: 210)

Moses is directing his speech to Pharaoh in this verse. /?aZ-Zann-u/ 'surmise' in this context stands for certainty that is based on evidence. The evidence is that the addressee is the one who arrogantly said before:

/?ana rabbukum ?al-?a9laa/ (Qur'an 79: 24)

I am your Lord, Most High (Ali 1938: 1682).

The verbs 'consider', 'think' and 'deem' in the second, third and fourth translations, 
respectively, have things in common. These are mental examination and making judgments which seem quite insufficient to communicate the sense of certainty based on evidence like our current case. However, the one whose mind handles all these mental processes is Moses, the messenger of God. In this particular case, the three verbs succeed in communicating the intended meaning. As for the first translation, the verb 'surmise' is not that precise in communicating the intended meaning. 'To surmise' means to infer from a slight evidence and this is not the case. The evidences that Moses had concerning the destruction of Pharaoh are many, not to mention his pride. Table 9 shows the various English translations of this form and their frequencies in the four Qur'anic translations.

Table 9. English Translations of the form /la-?aZunn-u-ka/ 'I do surmise that you'

\begin{tabular}{|c|c|c|c|c|}
\hline \multirow{2}{*}{ Translation } & \multicolumn{4}{|c|}{ Number of Occurrences } \\
\cline { 2 - 5 } & Ghâlî & Ali & Al-Hilâlî \& Khân & Pickthall \\
\hline surmise & 2 & - & - & - \\
\hline consider & - & 2 & - & - \\
\hline think & - & - & 2 & 2 \\
\hline deem & - & - & - & 2 \\
\hline Total & 2 & 2 & 2 & - \\
\hline
\end{tabular}

\section{9 /la-?aZunn-u-hu/'I do surmise that he'}

\section{/fa ?aTTali9a ?ilaa ?ilaahi muusaa wa ?inni la-?aZunn-u-hu kaaðibaal (Qur'an 40:37)}

I- . . ., (and) so view the God of Mûsâ, and surely I expect him to be a liar indeed (Ghâlî 2008: 471).

II- . . ., and that I may mount up to the God of Moses: but as far as I am concerned, I think (Moses) is a liar! (Ali 1938: 1273)

III- ... ., and I may look upon the Ilâh (God) of Mûsâ (Moses): But verily, I think him to be a liar

$$
\text { (Al-Hilâlî \& khân 1417H: 635). }
$$

IV - . . ., and may look upon the God of Moses, though verily I think him a liar (Pickthall 1930: 337).

As it is stated before, /?aZ-Zann-u/ 'surmise', when it comes from a disbeliever, indicates doubt and uncertainty. So we expect to see in the English translations verbs denoting doubt. However, one finds the two verbs 'expect' and 'think' which are used before with the opposite sense of certainty. The reason is that the speaker is Pharaoh who is well-known for his arrogance and pride. He is so blinded by his stubbornness that he is confident that Moses is a liar. The first translation, however, is the strongest and the most appropriate in visualizing the situation. Table 10 shows the various English translations of this form and their frequencies in the four Qur'anic translations.

Table 10. English Translations of the form /la-?aZunn-u-hu/'I do surmise that he'

\begin{tabular}{|c|c|c|c|c|}
\hline \multirow{2}{*}{ Translation } & \multicolumn{4}{|c|}{ Number of Occurrences } \\
\cline { 2 - 5 } & Ghâlî & Ali & Al-Hilâlî \& Khân & Pickthall \\
\hline expect & 2 & - & - & - \\
\hline think & - & 2 & 2 & 1 \\
\hline deem & - & - & - & 1 \\
\hline Total & 2 & 2 & 2 & 2 \\
\hline
\end{tabular}




\subsection{0 /ta-Zunn-u/ 'surmising'}

/wa wujuuhun yawma?iðin baasiratun ta-Zunn-u ?an yuf9ala bihaa faaqirah/ (Qur'an 75: 25)

I- And faces upon that Day shall be scowling. Expecting that a (back-breaking) calamity is going to be performed upon them (Ghâlî 2008: 578).

II- And some faces, that Day, will be sad and dismal, in the thought that some back-breaking calamity was about to be inflicted on them; ... (Ali 1938: 1652).

III- And some faces, that Day, will be Bâsirah (dark, gloomy, frowning, and sad), thinking that some calamity is about to fall on them (Al-Hilâlî \& Khân 1417H: 801).

IV- And that day will other faces be despondent, thou wilt know that some great disaster is about to fall on them (Pickthall 1930: 422).

The current verse describes the case of the disbelievers on the Day of Judgment. /ta-Zunn-u/ 'surmising' refers to the faces of the disbelievers and stands for certainty that is based on evidence. If it is life still, one would say /ta-Zunn-u/'surmising' stands for doubt because it comes from the disbelievers, but now life on earth is over and they see what they were promised and what they denied. Now, they are certain of their torture and ruin. The first translation is to the point in communicating the meaning of certainty doubled with the sense of expectancy. The fourth translation also succeeds in conveying the meaning of certainty based on evidence. However, the second and the third translations are not that precise in conveying the sense of certainty because there is no room for mental examination and thinking on that Day. Table 11 shows the various English translations of this form and their frequencies in the four Qur'anic translations.

Table 11. English Translations of the form /ta-Zunn- $u$ /'surmising'

\begin{tabular}{|c|c|c|c|c|}
\hline \multirow{2}{*}{ Translation } & \multicolumn{4}{|c|}{ Number of Occurrences } \\
\cline { 2 - 5 } & Ghâlî & Ali & Al-Hilâlî \& Khân & Pickthall \\
\hline expect & 1 & - & - & - \\
\hline think & - & 1 & 1 & 1 \\
\hline know & - & - & - & 1 \\
\hline Total & 1 & 1 & 1 & \\
\hline
\end{tabular}

\subsection{1 /ta-Zunn-uuna/ 'you all surmise'}

Iwa ta-Zunn-uuna ?il labiOtum ?illaa qaliilaal (Qur'an 17: 52)

I- . . and you surmise (that) decidedly you have not lingered except a little (Ghâlî 2008: 287).

II- . . , and ye will think that ye tarried but a little while! (Ali 1938: 708)

III- . . ., and you will think that you have stayed (in this world) but a little while! (Al-Hilâlî \& Khân 1417H: 375)

IV- ..., and ye will think that ye have tarried but a little while (Pickthall 1930: 207)

The context of /ta-Zunn-uuna/ 'you all surmise', this time, refers to something which is not 


\section{I Macrothink}

International Journal of Linguistics

ISSN 1948-5425

2013, Vol. 5, No. 6

certain and which is inferred from incomplete evidence. The situation is that when the believers compare life on earth to life in the Hereafter, the former will appear to be insignificant and worthless in their eyes. The two verbs in question, 'surmise' and 'think', adequately communicate the idea of uncertainty or rather making inferences from uncertain evidences. Table 12 shows the various English translations of this form and their frequencies in the four Qur'anic translations.

Table 12. English Translations of the form /ta-Zunn-uuna/ 'you all surmise'

\begin{tabular}{|c|c|c|c|c|}
\hline \multirow{2}{*}{ Translation } & \multicolumn{4}{|c|}{ Number of Occurrences } \\
\cline { 2 - 5 } & Ghâlî & Ali & Al-Hilâlî \& Khân & Pickthall \\
\hline surmise & 2 & - & - & - \\
\hline think & - & 1 & 1 & 1 \\
\hline imagine & - & 1 & - & - \\
\hline harbour & - & - & 1 & 2 \\
\hline Total & 2 & 2 & 2 & 1 \\
\hline
\end{tabular}

\subsection{2 /na-Zunn-u/'we surmise'}

/?in- na-Zunn-u ?illaa Zannaw wa maa naћnu bi-mustayqiniin/(Qur'an 45: 32)

I- . . . , decidedly we surmise about it (just) a surmise; and in no way have we reached certitude (Ghâlî 2008: 501).

II- . . we only think it is an idea, and we have no firm assurance (Ali 1938: 1363).

III-. . . we do not think it but as a conjecture, and we have no firm convincing belief (therein) (Al-Hilâlî \& Khân 1417H: 679)

IV- We deem it naught but a conjecture, and we are by no means convinced (Pickthall 1930: 357)

This Qur'anic context contains a sentential clue that locates the item /na-Zunn-u/ 'we surmise' in the area of uncertainty and doubt which is /wa maa nahnu bi-mustayqiniin/ 'and we have no firm belief.' As the verb 'to surmise' means to infer without solid foundation, the verb 'to think' is to make mental observation, and the verb 'to deem' means 'to think' as cited above in 3.4, therefore, the verbs used in the English translations of this Qur'anic verse succeed in communicating the intended meaning of uncertainty and doubt. Table 13 shows the various English translations of this form and their frequencies in the four Qur'anic translations.

Table 13. English Translations of the form /na-Zunn-u/ 'we surmise'

\begin{tabular}{|c|c|c|c|c|}
\hline \multirow{2}{*}{ Translation } & \multicolumn{4}{|c|}{ Number of Occurrences } \\
\cline { 2 - 5 } & Ghâlî & Ali & Al-Hilâlî \& Khân & Pickthall \\
\hline surmise & 1 & - & - & - \\
\hline think & - & 1 & 1 & - \\
\hline deem & - & - & - & 1 \\
\hline Total & 1 & 1 & 1 & 1 \\
\hline
\end{tabular}

\subsection{3 /na-Zunn-u-ka/ 'we surmise that you'}

Iwa maa ?anta ?illaa bašarum miOlunaa wa ?in na-Zunn-u-ka lamina lkaaðibiin/ (Qur'an 26: 186) 
I- And in no way are you (anything) except a mortal, like us, and decidedly we surmise that you are indeed one of the liars (Ghâlî 2008: 375).

II- Thou art no more than a mortal like us, and indeed we think thou art a liar! (Ali 1938: 968).

III- You are but a human being like us and verily, we think that you are one of the liars! (Al-Hilâlî \& khân 1417H: 500)

IV- Thou art but a mortal like us, and lo! we deem thee of the liars (Pickthall 1930: 270).

This form /na-Zunn-u-ka/ 'we surmise that you' is uttered by the companions of the wood to Shu9aib, the apostle. Since the speakers are disbelievers, the item /na-Zunn-u-ka/ 'we surmise that you' stands for doubt and uncertainty. Again, the three verbs that appear in the English translations of this Qur'anic verse, as indicated in 3.12, adequately communicate the intended meaning of uncertainty and doubt. Table 14 shows the various English translations of this form and their frequencies in the four Qur'anic translations.

Table 14. English Translations of the form /na-Zunn-u-ka/ 'we surmise that you'

\begin{tabular}{|c|c|c|c|c|}
\hline \multirow{2}{*}{ Translation } & \multicolumn{5}{|c|}{ Number of Occurrences } \\
\cline { 2 - 5 } & Ghâlî & Ali & Al-Hilâlî \& Khân & Pickthall \\
\hline expect & 1 & - & - & - \\
\hline think & - & 2 & 2 & - \\
\hline deem & - & - & - & - \\
\hline surmise & 1 & - & - & 2 \\
\hline Total & 2 & 2 & 2 & \\
\hline
\end{tabular}

\subsection{4 /na-Zunn-u-kum/'we surmise that you all'}

Iwa maa naraa lakum 9alaynaa min faDlim bal na-Zunn-u-kum kaaðibiin/(Qur'an 11:27)

I- And in no way do we see you have over us any grace. No indeed, we expect that you are liars (Ghâlî 2008: 224).

II- Nor do we see in you (all) any merit above us: In fact we think ye are liars! (Ali 1938: 520)

III- And we do not see in you any merit above us, in fact we think you are liars (Al-Hilâlî \& khân 1417H: 290).

IV- . . We behold in you no merit above us-nay, we deem you liars

(Pickthall 1930: 167).

In this Qur'anic context, the item /na-Zunn-u-kum/ 'we surmise that you all' is uttered by the disbelievers and directed to Noah and his followers. That is why it signifies doubt and uncertainty which are adequately conveyed by 'think' in the second and third translations and by 'deem' in the fourth translation. However, 'expect' in the first translation is the strongest of all. It is very rich for the situation as it includes other shadows of meaning. It reveals the disbelievers' blind confidence, determination and insistence on rejecting faith. Table 15 shows the various English translations of this form and their frequencies in the four Qur'anic translations. 
Table 15. English Translations of the form /na-Zunn-u-kum/ 'we surmise that you all'

\begin{tabular}{|c|c|c|c|c|}
\hline \multirow{2}{*}{ Translation } & \multicolumn{4}{|c|}{ Number of Occurrences } \\
\cline { 2 - 5 } & Ghâlî & Ali & Al-Hilâlî \& Khân & Pickthall \\
\hline expect & 1 & - & - & - \\
\hline think & - & 1 & 1 & 1 \\
\hline deem & - & - & - & 1 \\
\hline Total & 1 & 1 & 1 & - \\
\hline
\end{tabular}

\subsection{5 /ya-Zunn-u/ 'he surmises'}

\section{/?alaa yaZunn-u ?ulaa?ika ?annahum mmab9uuӨuuna liyawmin 9aZiim/(Qur'an 83:4)}

I- Do those not expect that they will be made to rise again (Ghâlî 2008: 587)

II- Do they not think that they will be called to account? on a Mighty Day (Ali 1938: 1703)

III- Do they not think that they will be resurrected (for reckoning), on a Great Day? (Al-Hilâlî \& Khân 1417H: 821)

IV- Do such (men) not consider that they will be raised again unto an awful Day (Pickthall 1930: 433)

The above verse revolves in the sphere of /?at-taTfiifl 'stinting'. The form of the verb /ya-Zunn-u/ 'he surmises' agrees with the $3^{\text {rd }}$ person singular and plural. In the case of the $3^{\text {rd }}$ person plural, the verb should precede the subject as it is the case in the current verse. The question in this verse is exclamatory. /?aZ-Zann- $u /$ 'surmise', here, stands for certainty which is based on careful thinking and contemplation. The verbs 'expect', 'think' and 'consider' that appear in the four English translations could communicate the intended meaning. However, 'expect' is favoured with the inclusion of the sense of expectancy which strengthens the meaning of certainty revealed in the current verse. Table 16 shows the various English translations of this form and their frequencies in the four Qur'anic translations.

Table 16. English Translations of the form /ya-Zunn-u/ 'he surmises'

\begin{tabular}{|c|c|c|c|c|}
\hline \multirow{2}{*}{ Translation } & \multicolumn{4}{|c|}{ Number of Occurrences } \\
\cline { 2 - 5 } & Ghâlî & Ali & Al-Hilâlî \& Khân & Pickthall \\
\hline surmise & 1 & - & - & - \\
\hline think & - & 2 & 2 & - \\
\hline expect & 1 & - & - & 1 \\
\hline consider & - & - & - & 2 \\
\hline Total & 2 & 2 & 2 & \\
\hline
\end{tabular}

\subsection{6 /ya-Zunn-uuna/ 'they surmise'}

/?allðiina ya-Zunn-uuna ?anna-hum mulaaquu rabbihim wa ?anna-hum ?ilayhi raaji9uun/ (Qur'an 2: 46)

I- Who expect that they are meeting their Lord and that to Him they are returning (Ghâlî 2008: 7).

II- Who bear in mind the certainty that they are to meet their Lord, and that they are to return to $\operatorname{Him}$ (Ali 1938: 28). 
III- (They are those) who are certain that they are going to meet their Lord, and that unto Him they are going to return (Al-Hilâlî \& Khân 1417H: 11).

IV- Who know that they will have to meet their Lord, and that unto Him they are returning (Pickthall 1930: 37).

This verse describes humble people who are certain that they will return to their Lord in the Hereafter. Iya-Zunn-uunal 'they surmise' obviously indicates certainty in this context. The four translations succeed in communicating this sense of certainty. The first translation uses 'expect' which implies the meanings of certainty, confidence and anticipation. The second translation uses 'bear in mind' followed by the noun phrase 'the certainty' to leave no room for doubt. The third translation uses the stative verb 'be' followed by an adjective: 'are certain.' And the fourth translation uses 'know' that is derived from knowledge which separates certainty from uncertainty. Table 17 shows the various English translations of this form and their frequencies in the four Qur'anic translations.

Table 17. English Translations of the form /ya-Zunn-uuna/'they surmise'

\begin{tabular}{|c|c|c|c|c|}
\hline \multirow{2}{*}{ Translation } & \multicolumn{4}{|c|}{ Number of Occurrences } \\
\cline { 2 - 5 } & Ghâlî & Ali & Al-Hilâlî \& Khân & Pickthall \\
\hline expect & 2 & - & - & - \\
\hline bear in mind & - & 1 & - & - \\
\hline (to be) certain & - & - & 1 & - \\
\hline know & - & - & 1 & - \\
\hline surmise & 3 & - & - & - \\
\hline conjecture & - & 2 & 1 & 2 \\
\hline guess & - & - & 1 & - \\
\hline (to be) convinced & - & 1 & - & - \\
\hline moved by wrong suspicions & - & 1 & - & 1 \\
\hline think & - & - & 1 & 5 \\
\hline Total & 5 & 5 & 5 & \\
\hline
\end{tabular}

\subsection{7/?aZ-Zann-u/ 'surmise' (noun)}

Jyaa ?ayyuha llaðiina ?aаmanu jtanibuu kaӨiiram mina ZZan/(Qur'an 49: 12)

I- O you who have believed, avoid much surmise (Ghâlî 2008: 517).

II- O ye who believe! Avoid suspicion as much (as possible) (Ali 1938: 1406).

III- O you who believe ! Avoid much suspicion （Al-Hilâlî \& Khân 1417H: 700).

IV- O ye who believe! Shun much suspicion (Pickthall 1930: 369).

In this verse, there is an advising Divine Imperative to avoid baseless doubts because they harm innocent people. /?aZ-Zann-u/ 'surmise' positively equals doubt in this context. This sense of doubt is directly communicated in the second, third and fourth translations by the choice of the word 'suspicion'. However, the first translation communicates the same sense of doubt but in the somewhat more euphemistic expression 'surmise' which transfers the same sense but in an indirect or veiled way. Table 18 shows the various English translations of this form and their frequencies in the four Qur'anic translations. 
Table 18. English Translations of the form /?a-Z-Zann-u/ 'surmise (noun)'

\begin{tabular}{|c|c|c|c|c|}
\hline \multirow{2}{*}{ Translation } & \multicolumn{4}{|c|}{ Number of Occurrences } \\
\cline { 2 - 5 } & Ghâlî & Ali & Al-Hilâlî \& Khân & Pickthall \\
\hline surmise & 15 & - & - & - \\
\hline suspicion & - & 3 & 2 & 2 \\
\hline think & - & 3 & 4 & 4 \\
\hline conjecture & - & 6 & 4 & 3 \\
\hline opinion & - & 1 & - & 3 \\
\hline guess & - & - & 4 & - \\
\hline fancy & - & 2 & - & - \\
\hline consideration & - & - & 1 & 15 \\
\hline Total & 15 & 15 & 15 & \\
\hline
\end{tabular}

\subsection{8 /Zann-aa/'surmise' (noun)}

/wa maa yattabi9u ?akӨaruhum ?illaa Zann-aal (Qur'an 10: 36)

I- And in no way do most of them ever follow anything except surmise (Ghâlî 2008: 213).

II- But most of them follow nothing but fancy (Ali 1938: 494).

III- And most of them follow nothing but conjecture (Al-Hilâlî \& Khân 1417H: 275).

IV- Most of them follow naught but conjecture (Pickthall 1930: 160).

The current verse refers to those who make false gods partners of God. In doing so, they follow no solid evidence but doubt. Accordingly, the item /Zann-aa/ 'surmise' stands for doubt since the people concerned are polytheists. The four translations successfully communicate this sense of doubt. The first translation uses 'surmise' which, as it is mentioned above, stands for making inferences from uncertain evidences. The second translation uses 'fancy' which means "to believe without proof" (Funk \& Wagnalls 1967:1/458). As for the third and the fourth translations, they use 'conjecture' which "often indicates mere guesswork" (Wierzbicka 1987: 266). That is to say "the person putting forward a conjecture could not offer proof" (Ibid). This is how the four translations adequately translate the item /Zann-aa/ 'surmise' as it is intended in the above verse. However, the most accurate translation of all is the second. The word 'fancy' not only indicates the absence of proof but also indicates other shadows of meaning like imagination, error and illusion as well. Table 19 shows the various English translations of this form and their frequencies in the four Qur'anic translations.

Table 19. English Translations of the form /Zann-aa/ 'surmise (noun)'

\begin{tabular}{|c|c|c|c|c|}
\hline \multirow{2}{*}{ Translation } & \multicolumn{4}{|c|}{ Number of Occurrences } \\
\cline { 2 - 5 } & Ghâlî & Ali & Al-Hilâlî \& Khân & Pickthall \\
\hline surmise & 2 & - & - & - \\
\hline fancy & - & 1 & - & - \\
\hline conjecture & - & - & 2 & - \\
\hline idea & - & 1 & - & 2 \\
\hline Total & 2 & 2 & 2 & \\
\hline
\end{tabular}

\subsection{9 /Zann-u-kum/'your surmise'}

Ifamaa Zann-u-kum birabbi l9aalamiin/ (Qur'an 37: 87) 
I- What then is your expectation from the Lord of the worlds? (Ghâlî 2008: 449)

II- "Then what is your idea about the Lord of the Worlds?" (Ali 1938: 1202)

III- "Then what think you about the Lord of the 'Âlamîn (mankind, jinn, and all that exists)?" (Al-Hilâlî \& Khân 1417H: 602)

IV- What then is your opinion of the Lord of the Worlds? (Pickthall 1930: 321)

The same idea of making false gods partners of God by polytheists is continued, here, in this verse. This verse also presents a warning in a question form. The item /Zann-u-kum/ 'your surmise' stands, again, for doubt and uncertainty as it is originated from those polytheists. It is translated as 'expectation' in the first Qur'anic translation which stands for "an attitude of expectancy or hope" (Hanks 1986: 535). The second, third and fourth Qur'anic translations use 'idea', 'think' and 'opinion', respectively. The word 'idea' is defined as "a mental representation of something" (Funk \& Wagnalls 1967: 1/626). The word 'think', as it is said before, stands for mental examination of something. Finally, the word 'opinion' is defined as "a conclusion or judgment held with confidence, but falling short of positive knowledge" (Ibid: 2/885). Obviously, the four items are characterized by the absence of the sense of certainty. They also confirm how foolish those polytheists are. However, there is a minute difference in meaning in the four translations. The first translation asks about what will happen to those polytheists on the Day of Judgment as a result of their misconceptions. The other three translations, on the other hand, ask about their ideas/thoughts/opinions that led them to be what they are in this world as if the sense of anticipation that characterizes the word 'expectation' creates a kind of shift from this world to the other world. Table 20 shows the various English translations of this form and their frequencies in the four Qur'anic translations.

Table 20. English Translations of the form /Zann-u-kum/ 'your surmise'

\begin{tabular}{|c|c|c|c|c|}
\hline \multirow{2}{*}{ Translation } & \multicolumn{4}{|c|}{ Number of Occurrences } \\
\cline { 2 - 5 } & Ghâlî & Ali & Al-Hilâlî \& Khân & Pickthall \\
\hline expectation & 1 & - & - & - \\
\hline idea & - & 1 & - & 1 \\
\hline think & - & 1 & 2 & 1 \\
\hline opinion & - & - & - & - \\
\hline surmise & 1 & - & - & 2 \\
\hline Total & 2 & 2 & 2 & - \\
\hline
\end{tabular}

\subsection{0 /Zann-a-hu/'his surmise'}

Iwa laqad Saddaqa 9alayhim ?iblysu Zann-a-hu/ (Qur'an 34:20)

I- And indeed Iblîs already verified his expectation of them (Ghâlî 2008: 430).

II- And on them did Satan prove true his idea (Ali 1938: 1140).

III- And indeed Iblis (Satan) did prove true his thought about them (Al-Hilâlî \& Khân 1417H: 576).

IV- And Satan indeed found his calculation true concerning them (Pickthall 1930: 309). 
In the current verse, the item /Zann-a-hu/ 'his surmise', again, stands for the sense of uncertainty that lacks any solid foundations. Satan has promised to tempt mankind and his 'calculation' was confirmed in the case of the people of Saba?, a city in Yemen. The four translations succeed in communicating the meaning intended in this verse, especially the fourth one that uses the word 'calculation' which means "forecast" (Hawkins \& Allen 1991: 208; Hanks 1986: 223; Funk \& Wagnalls 1967: 1/188). Table 21 shows the various English translations of this form and their frequencies in the four Qur'anic translations.

Table 21. English Translations of the form /Zann-a-hu/ 'his surmise'

\begin{tabular}{|c|c|c|c|c|}
\hline \multirow{2}{*}{ Translation } & \multicolumn{4}{|c|}{ Number of Occurrences } \\
\cline { 2 - 5 } & Ghâlî & Ali & Al-Hilâlî \& Khân & Pickthall \\
\hline expectation & 1 & - & - & - \\
\hline idea & - & 1 & - & - \\
\hline thought & - & - & 1 & 1 \\
\hline calculation & - & - & - & 1 \\
\hline Total & 1 & 1 & 1 & \\
\hline
\end{tabular}

\subsection{1 /?aZ-Zunuunaa/ 'surmises'}

Iwa balagati lquluubu lhanaajira wa taZunnuuna bi-llaahi ZZunuunaa/ (Qur'an 33:10)

I- . . and hearts reached to the larynxes; and you surmised vain surmises about Allâh (Ghâlî 2008: 419).

II- . . . and the hearts gaped up to the throats, and ye imagined various (vain) thoughts about God! (Ali 1938: 1106)

III- . . . and the hearts reached to the throats, and you were harbouring doubts about Allâh (Al-Hilâlî \& Khân 1417H: 561).

IV - . . a and hearts reached to the throats, and ye were imagining vain thoughts concerning Allah (Pickthall 1930: 302).

The scene in this verse is the Battle of the Trench and the people addressed are the hypocrites. The item /?aZ-Zunuunaa/ 'surmises' is the plural form of /?aZ-Zann-u/ 'surmise' and it is attributed to the hypocrites. Accordingly, the item /?aZ-Zunuunaa/ 'surmises' stands for doubts and uncertainty. This meaning is communicated in the first Qur'anic translation by the use of the word 'surmises' modified by 'vain'. The second translation uses the word 'thoughts' modified by 'vain'. The third translation uses 'doubts' preceded by the lexical verb 'harbouring' and the fourth uses 'thoughts' modified by 'vain'. In fact, the use of 'vain' as a modifier in the first, second and fourth translations confirms that /?aZ-Zann-u/ 'surmise', on the part of the hypocrites, stands for doubts and uncertainty. It is worth mentioning that the third translation is the most accurate since it straightforwardly uses the word 'doubts' preceded by the lexical verb 'harbouring' which implies the concealment of thoughts and mental reservation. Table 22 shows the various English translations of this form and their frequencies in the four Qur'anic translations. 
Table 22. English Translations of the form /?a-Z-Zunuunaa/ 'surmises'

\begin{tabular}{|c|c|c|c|c|}
\hline \multirow{2}{*}{ Translation } & \multicolumn{4}{|c|}{ Number of Occurrences } \\
\cline { 2 - 5 } & Ghâlî & Ali & Al-Hilâlî \& Khân & Pickthall \\
\hline surmises & 1 & - & - & - \\
\hline thoughts & - & 1 & - & 1 \\
\hline doubts & - & - & 1 & - \\
\hline Total & 1 & 1 & 1 & 1 \\
\hline
\end{tabular}

\subsection{2 /?aZ-Zaanniina/ 'they who surmise'}

\section{/?aZ-Zaanniina bi-llaahi Zanna-ssaw?i 9alayhim daa?iratu-ssaw?/ (Qur'an 48: 6)}

I- . . ., the ones surmising ill surmises of Allâh. Against them will be the woeful turn of fortune (Ghâlî 2008: 511).

II- . . , who imagine an evil opinion of God. On them is a round of Evil (Ali 1938: 1392)

III- . . ., who think evil thoughts about Allâh: for them is a disgraceful torment. (Al-Hilâlî \& Khân 1417H: 693)

IV-. . ., who think an evil thought concerning Allah. For them is the evil turn of fortune (Pickthall 1930: 365)

Table 23 shows the various English translations of this form and their frequencies in the four Qur'anic translations.

Table 23. English Translations of the form /?a-Z-Zaanniina/ 'they who surmise'

\begin{tabular}{|c|c|c|c|c|}
\hline \multirow{2}{*}{ Translation } & \multicolumn{4}{|c|}{ Number of Occurrences } \\
\cline { 2 - 5 } & Ghâlî & Ali & Al-Hilâlî \& Khân & Pickthall \\
\hline the ones surmising & 1 & - & - & - \\
\hline who imagine & - & 1 & - & 1 \\
\hline who think & - & - & 1 & 1 \\
\hline Total & 1 & 1 & 1 & - \\
\hline
\end{tabular}

In the current verse, the item /?aZ-Zaanniina/ 'they who surmise' stands for both hypocrites and polytheists. Since they both are evil people, their thoughts are as evil as they are. Accordingly, /?aZ-Zann-u/ 'surmise', in this context, stands again for doubts and uncertainty. The four English translations render the item /?aZ-Zaanniina/ 'they who surmise' as 'the ones surmising', 'who imagine', 'who think' and 'who think', respectively. In this way, the meanings indicated in the four translations are limited within the frame of uncertainty and doubts stressing the lack of solid evidence. This is how the four translations adequately communicate the meaning as it is intended in the Qur'anic text. To sum up, Table 24 presents the translations of the representative examples of the twenty-two forms of the contronym IZann-a/ 'to surmise' in the Glorious Qur'an. 
Table 24. Translations of the representative examples of the contronym /Zann-a/ 'to surmise' in the Glorious Qur'an

\begin{tabular}{|c|c|c|c|c|c|}
\hline \multirow[t]{2}{*}{ Meaning } & \multirow[t]{2}{*}{ Translation } & \multicolumn{4}{|c|}{ Number of Occurrences } \\
\hline & & Ghâlî & Ali & Al-Hilâlî \& Khîn & Pickthall \\
\hline \multirow{12}{*}{ 怘 } & expect & 8 & - & - & - \\
\hline & consider & - & 2 & - & 2 \\
\hline & know & - & - & 1 & 5 \\
\hline & feel & - & 1 & 1 & - \\
\hline & understand & - & 1 & - & - \\
\hline & believe & - & - & 1 & - \\
\hline & apprehend & - & 1 & 1 & - \\
\hline & surmise & 1 & - & - & - \\
\hline & think & - & 3 & 4 & 1 \\
\hline & deem & - & - & - & 1 \\
\hline & bear in mind & - & 1 & - & - \\
\hline & (to be) certain & - & - & 1 & - \\
\hline \multirow{13}{*}{$\begin{array}{l}\stackrel{\overrightarrow{0}}{0} \\
\stackrel{0}{0}\end{array}$} & surmise & 9 & - & - & - \\
\hline & think & - & 7 & 10 & 4 \\
\hline & deem & - & 1 & - & 4 \\
\hline & suppose & - & - & - & 1 \\
\hline & expect & 4 & - & - & - \\
\hline & suspicion & - & 1 & 1 & 1 \\
\hline & fancy & - & 1 & - & - \\
\hline & conjecture & - & - & 1 & 1 \\
\hline & idea & - & 2 & - & - \\
\hline & opinion & - & - & - & 1 \\
\hline & calculation & - & - & - & 1 \\
\hline & doubts & - & - & 1 & - \\
\hline & imagine & - & 1 & - & - \\
\hline & tal & 22 & 22 & 22 & 22 \\
\hline
\end{tabular}

\section{Conclusion}

The present study shows how sense relations are evident in both Arabic and English. What differs is the technical terminology describing or naming these sense relations. Prominent among the sense relations in Arabic is the phenomenon of /?al-?aDdaad/ 'contronyms'. This phenomenon refers to a double-faced word or rather a single word which stands for two opposite meanings. In Arabic, this phenomenon has many justifications, amongst which are the widening of lexical meaning and the many dialects of the Arabic language. This sense relation is said to be problematic because it causes ambiguity. Hence the role of the context in disambiguating the meaning of the lexical item in question.

The lexical item /Zann-a/ 'to surmise' is mentioned, in the Glorious Qur'an, sixty-nine times in twenty-two different forms: IZann-a/ 'he surmised', IZann-aal 'they two surmised', /Zanan-tu/ 'I surmised', /Zanan-tum/ 'you all surmised', IZanan-naa/ 'we surmised', /Zann-uu/ 'they surmised', /?aZunn-u/ 'I surmise', /la-?aZunn-u-kal 'I do surmise that you', /la-?aZunn-u-hu/ 'I do surmise that he', Ita-Zunn-u/ 'surmising', Ita-Zunn-uu-nal 'you all surmise', Ina-Zunn-u/ 'we surmise', Ina-Zunn-u-kal 'we surmise that you', Ina Zunn-u-kum/ 'we surmise that you all', /ya-Zunn-u/ 'he surmises', /ya-Zunn-uu-nal 'they surmise', l?aZ-Zann-u/ 'surmise (noun)', IZann-aal 'surmise (noun)', IZann-u-kum/ 'your surmise', /Zann-a-hu/ 'his surmise', /?aZ-Zunuunaa/ 'surmises', and /?aZ-Zaanniina/ 'they who surmise'. The present study discusses a representative example of every form. 


\section{Al Macrothink}

International Journal of Linguistics ISSN 1948-5425 2013, Vol. 5, No. 6

The present paper discusses the occurrences of the lexical item /?aZ-Zann-u/ 'surmise' as a representative of the phenomenon of /?al-?aDdaad/'contronyms' in the Glorious Qur'an. Out of the twenty-two examples discussed above, nine occurrences denote certainty and thirteen occurrences denote uncertainty and doubt. Context clues and the Qur'anic interpretation help to solve the ambiguity of this double-faced lexical item /?aZ-Zann-u/ 'surmise'.

The four English translations use different verbs to translate the verb /Zann-a/ 'surmised' into English. The variation among the four translations depends on whether the meaning of the Arabic verb stands for certainty or doubt. The first translation, (Ghâlî 2008), is distinguished by the use of the verb 'to expect' for certainty and the verb 'to surmise' for doubt in the majority of the examples discussed. 'To expect' is distinguished from the other verbs used in the other three translations by the minute senses of expectancy, hope and anticipation. 'To surmise', on the other hand, euphemistically stands for doubt and uncertainty. However, sense-relations are very complicated and every Qur'anic translation has its own touches in clarifying the various shadows of meaning encapsulated in the Qur'anic verses discussed.

\section{References}

Al-9askari, Abu Hilal. (1997). Al-Furuuq Al-lugawiyah [Linguistic Differences]. Verified by Muhammad Ibrahim Selim. Cairo: Dar Al-9ilm wa Al-Thaqafah.

Al-Anbari, Muhammad Ibn Al-Qasim. (1987). Kitab ?al-?aDdaad [The book of Contronyms]. Verified by Muhammad Abu Al-FaDl Ibrahim. Saida: Al-Maktabah Al-9aSriyah.

Al-Hilâlî, Muhammad Taqî-ud-Din, \& Khân, Muhammad Muhsin (Trans.) (1417H). ?al-qur'an-u l-kariim wa-tarjamat-u ma9aaniih-i ?ila l-lugat-i i-inkliiziyyah [Translation of the Meanings of the Noble Qur'an In The English Language]. Madina: King Fahd Complex for the Printing of the Holy Qur'an.

Ali, Abdullah Yusuf (Trans.) (1938). The Holy Qur'an: Translation and Commentary. (3 ${ }^{\text {rd }}$ ed.). Beirut: Dar Arabia.

Al-Saleh, Hussein Hamed. (2010). Zahirat At-taDaad Ad-dilali fii Al-qur'an Al-karim [The Phenomenon of Semantic Oppositeness in The Glorious Qur'an]. Yemeni Studies Journal, 80, 159-199.

Al-Samara?i, Ibrahim. (1997). ?at-taTawur ?al-lugawi ?at-taariixi [Historical Linguistic Development]. Beirut: Dar Al-Andalus.

Al-Shawkani, M. A. M. (1983). Fath Al-qadiir [The Inspiration of the Almighty]. 5 Vols. Beirut: Dar Al-fikr.

Funk and Wagnalls. (1967). Standard Dictionary: International Edition. 2 Vols. New York: Funk and Wagnalls Company. 


\section{Macrothink}

International Journal of Linguistics ISSN 1948-5425 2013, Vol. 5, No. 6

Gadalla, Hassan. (2000). Comparative Morphology of Standard and Egyptian Arabic. Muenchen, Germany: Lincom Europa.

Ghâlî, Muhammad Mahmûd (Trans.) (2008). Towards Understanding The Ever-Glorious Qur'ân (5th ed.). Cairo: Dar An-nashr Liljami9at.

Haidar, Farid Awad. (2005). 9ilm ?ad-dilalah [Semantics]. Cairo: Maktabat Al-Adab.

Hanks, Patrick (Ed.) (1986). Collins Dictionary of the English Language. (2 ${ }^{\text {nd }}$ ed.) London and Glasgow: William Collins Sons \& Co.Ltd.

Hawkins, Joyce M., \& Allen, Robert (Eds.) (1991). The Oxford Encyclopedic English Dictionary. Oxford: Clarendon Press.

Hendrickson, Robert. (2008). The Facts On File Encyclopedia Of Word And Phrase Origins (4th ed.). New York: Facts On File, Inc.

Hudson, Grover. (2000). Essential Introductory Linguistics. Oxford and Massachusetts: Blackwell Publishers.

Ibn ManZur. (1981). Lisanu Al-Arab [The Tongue of the Arabs]. 6 Vols; Cairo: Dar Al-Ma'aarif.

Lederer, Richard. (1979). More Curious Contronyms. Word Ways, 12(3). [Online] Available: http://digitalcommons. butler.edu/wordways/vd12/iss3/14 (August 24, 2013).

Lyons, John. (1977). Semantics. 2 Vols; Cambridge: Cambridge University Press. Vol I.

NaSSar, Hussein. (2003). Madxal Ta9riif ?al-?aDdaad [Introduction to Contronyms] (1st ed.). Cairo and Port Said: Maktabat Al-Thaqafah Al-diniyah.

Newmark, Peter. (1988). Approaches to Translation. London: Prentice Hall International Ltd.

Palmer, F. R. (1981). Semantics (2nd ed.). Cambridge: Cambridg University Press.

Pickthall, Mohammed Marmaduke. (Trans.) (1930). The Meaning of the Glorious Koran. New York: The New American Library, Inc.

Radford, A., Atkinson, M., Britain, D., Clahsen, H., \& Spencer, A. (1999). Linguistics: An Introduction. Cambridge: Cambridge University Press.

Wierzbicka, Anna. (1987). English Speech Act Verbs: A Semantic Dictionary. Sydney: Academic Press. 


\section{Macrothink}

\section{Appendix}

Symbols used in the phonemic transcription of Arabic forms

A. The consonants of Standard Arabic:

\begin{tabular}{|c|c|c|c|c|c|c|c|c|c|c|c|}
\hline \multicolumn{2}{|l|}{ Place } & \multirow[b]{2}{*}{ 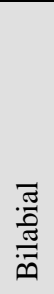 } & \multirow[b]{2}{*}{ 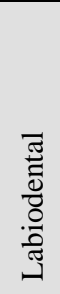 } & \multirow[b]{2}{*}{ 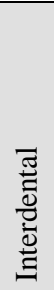 } & \multicolumn{2}{|c|}{$\begin{array}{l}\text { Dento- } \\
\text { Alveolar }\end{array}$} & \multirow[b]{2}{*}{ 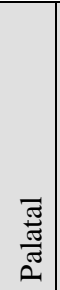 } & \multirow[b]{2}{*}{$\frac{\dot{z}}{j}$} & \multirow[b]{2}{*}{$\frac{\sqrt{\frac{3}{3}}}{3}$} & \multirow[b]{2}{*}{ 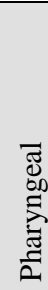 } & \multirow[b]{2}{*}{ 鸪 } \\
\hline Manner & Voicing & & & & 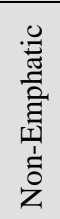 & 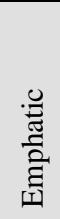 & & & & & \\
\hline Stop & $\begin{array}{l}\text { Voiceless } \\
\text { Voiced }\end{array}$ & $\mathrm{b}$ & & & $\begin{array}{l}\mathrm{t} \\
\mathrm{d}\end{array}$ & $\begin{array}{l}\mathrm{T} \\
\mathrm{D}\end{array}$ & & $\mathrm{k}$ & $q$ & & $?$ \\
\hline Fricative & $\begin{array}{l}\text { Voiceless } \\
\text { Voiced }\end{array}$ & & f & $\begin{array}{l}\theta \\
\partial\end{array}$ & $\begin{array}{l}\mathrm{s} \\
\mathrm{z}\end{array}$ & $\begin{array}{l}\mathrm{S} \\
\mathrm{Z}\end{array}$ & $\check{\mathrm{s}}$ & $\begin{array}{l}\mathrm{x} \\
\mathrm{g}\end{array}$ & & $\begin{array}{l}\hbar \\
9\end{array}$ & $\mathrm{~h}$ \\
\hline Affricate & Voiced & & & & & & $\mathrm{j}$ & & & & \\
\hline Flap & Voiced & & & & $\mathrm{r}$ & & & & & & \\
\hline Lateral & Voiced & & & & 1 & & & & & & \\
\hline Nasal & Voiced & $\mathrm{m}$ & & & $\mathrm{n}$ & & & & & & \\
\hline Glide & Voiced & $\mathrm{W}$ & & & & & $\mathrm{y}$ & & & & \\
\hline
\end{tabular}

B. The vowels of Standard Arabic:

\begin{tabular}{|l|c|c|c|c|c|c|}
\hline \multirow{2}{*}{} & \multicolumn{3}{|c|}{ Short } & \multicolumn{3}{c|}{ Long } \\
\cline { 2 - 7 } & Front & Central & Back & Front & Central & Back \\
\hline High & $\mathrm{i}$ & & $\mathrm{u}$ & ii & & uu \\
\hline Mid & & & & & & \\
\hline Low & & $\mathrm{a}$ & & & aa & \\
\hline
\end{tabular}

Note: The two tables are adapted from Gadalla (2000). 